\title{
BUDAYA HUKUM DALAM KEBERLAKUAN \\ UNDANG-UNDANG NOMOR 28 TAHUN 2014 TENTANG \\ HAK CIPTA PADA PENGRAJIN PERAK DI BALI
}

\section{Oleh:}

\author{
Kadek Julia Mahadewi ${ }^{1}$
}

\begin{abstract}
The Law No.28 year of 2014 regarding Copyright set about the protection of copyright works, one form of copyright works which is being protected is silver handicrafts. In Bali it is popular for its silver handicrafts which its motif is unique and creative so that the existence of silver handicrafts can penetrate international and domestic market.Silversmiths in Bali in producing works of silver handicrafts, in which they found the problem that they had to face such as the case that fallen upon silversmiths in creating their works as follows, first, there were the products of Balinese silver handicrafts registered its copyright by foreign party. The case was experienced by Desak Nyoman Suarti against Lois Hill the businessman from USA.Second,it is accused toward Balinese silversmith that he copied silver handicraft's copyright owned by foreign party, it was happening toward Balinese craftsman Ketut Deni Aryasa against John Hardy the owner of PT.Karya Tangan Indah.It certainly harms Balinese silversmiths when the truth is that silver handicrafts can be protected by Copyright Law No.28 year of 2014 in the article of 38.From the issues mentioned above we conducted the research titled: Legal Culture in the Enforceability of the Law No.28 year of 2014 Regarding Copyright of the Balinese Silversmiths. The type of this research belonged to the study of empirical law. The result of research shows that, first, the type of law protection provided by the state towards traditional motifs is in the form of preventive and repressive law protection. Second, legal culture of silversmiths in Bali view traditional motifs as a work substance with work orientation is for a living so that value system being adopted by most silversmiths in Bali is not to register their works into the Copyright system.
\end{abstract}

\section{Keywords: Legal Culture, the Enforcement of Copyright Law, Balinese Silversmi}

\section{PENDAHULUAN}

\subsection{Latar Belakang}

Corak dan warna hukum dipengaruhi olehmasyarakat, sehinggahukum merupakan manifestasi dari nilai-nilai kehidupan di mana hukum itu berlaku. Hukum merupakan cerminan budaya masyarakat yang memilikinya. Selain hukum mempunyai sifat

Mahasiswa Magister Ilmu Hukum Universitas Udayana, Denpasar, Bali. Alamat Jl. Kapten Agung No.7A Denpasar, e-mail: juliamahadewi@gmail. com universal, juga mempunyai sifat nasional, di mana hukum suatu negara atau masyarakat yang satu berbeda dengan hukum negara atau masyarakat yang lain, karena filsafat hidup bangsa yang satu tidak sama dengan bangsa yang lain ini disebabkan oleh faktor geografis, kepribadian dan kebudayaan yang berbeda antara masyarakat satu masyarakat bangsa yang lain. ${ }^{2}$

Riduan Syahrani, 2011, Rangkuman Intisari Ilmu Hukum, PT. Citra Aditya, Bandung, hlm. 28. 
Hak Kekayaan Intelektual (HKI) adalah istilah umum dari hak eksklusif yang diberikan sebagai hasil yang diperoleh dari kreativitas atau kegiatanmanusia, sebagai tanda yang digunakan dalam kegiatan bisnis dan termasuk ke dalam hak tidak berwujud yang memiliki nilai ekonomis. ${ }^{3}$ Suatu karya intelektual yang mendapat perlindungan hak cipta apabila telahdiwujudkan sebagai ciptaan yang berwujud atau berupa ekspresi yang dapat dilihat, didengar dan dibaca. Hukum hak cipta tidak melindungi ciptaan yangmasih berupaidesemata.

Secara mendalam tentang hukum hak cipta dapat ditelusuri melalui dasar hukum pengaturannya.Di Indonesia secara nasional hakciptadiaturdalamUndang-undang Nomor 28 Tahun 2014 Tentang Hak Cipta. Secara Internasional pengaturan tentang hak cipta dapat diketahui melalui Konvensi seperti: Berne Convention, Universal Copyright Convention sertaTRIPsAgreement.

Hak cipta adalah hak eksklusif bagi pencipta atau penerima hak untukmengumumkan atau memperbanyak ciptannya atau memberikan izin untuk itu,dengan tidak mengurangi pembatasanpembatasan menurut peraturan perundangundangan yang berlaku. Untuk mengetahui kriteria agar ciptaan dapat dilindungi hak cipta adalah:

a. Harus orisinil yaitu hasil kerativitas pencipta sendiri bukan mengcopy;

Mastur, Perlindungan Hukum Hak Kekayaan Intelektual di Bidang Paten, Jurnal Ilmiah Hukum Vol6, No1, Edisil Januari 2012, Fakultas Hukum, UniversitasWahid Hasyim Semarang. b. Ada bentuk nyata atau kongkrit misalnya diekspresikan dalam kertas, audio, videotape, CD, kanvas dan sebagainya.

c. Harus terdapat beberapa kreativitas artinya harus dapat diproduksi dengan suatu alat olehseseorang.

Dalam Undang-undang Nomor 28 Tahun 2014 Hak Cipta, berdasarkan Pasal 1 angka 3. Ciptaan adalah setiaphasil karya ciptadi bidang ilmu pengetahun, seni dan sastra yang dihasilkan atas inspirasi, kemampuan, pikiran,imajinas i,kecekatan, keterampilan atau keahlian yang diekspresikan dalam bentuk nyata. Ciptaan atau karya cipta disini mendapat perlindungan apabila menunjukan keaslian sebagai ciptaan seseorang yang bersifat pribadi.Berkaitan dengan permasalahan hak cipta para pengrajin perak di Bali mengalami permasalahan hukum dalam perlindungan terhadap motif tradisional perak Bali seperti adanya gugatan pelanggaran motiftradisional perak oleh pihak asing. Telah didaftarkannya motif tradisional Bali oleh perusahaan/orang asing dalam pendaftaraan hak cipta.

Pentingnya perlindungan terhadap motif-motif kerajinan tradisional perak Bali berkaitan dengan hak cipta para pengrajin perak di Bali saat ini mulai mengalami masalah hukum seperti gugatan pelanggaran hak cipta akibat didaftarkan motif tradisional perak Bali oleh perusahaan /orang asing. Apabila ditelusuri barang-barang kerajinan perak tersebut keberadaannya sebenarnya sudah ada dan dipakai oleh pengrajin di Bali secara turun-temurun, bahkan dari motif tersebut sudah tidak diketahui siapakah penciptanya sehingga desainnya 
dapat dikatakan telah menjadi milik masyarakat Bali (public domain). Perbuatan perusahaan/orang asing yang mendaftarkan motif barang kerajinan khas Bali di luar negeri telah membuat kerugian secara langsung bagi pengrajin perak Bali dengan memanfaatkan kelemahan pengrajin perak Bali akibat ketidakwaspadaanya terhadap eksploitasi orang asing akan warisan budaya Indonesia merugikan nilai ekonomi karya tersebut. Pentingnya perlindungan hukum terhadap motif tradisional Bali mempunyai nilai strategis. Dilihat dari segi budaya, dengan adanya perlindungan terhadap motif kerajinan perak Bali maka pelestarian budaya bangsa akan tercapai tidak ada klaim budaya lagi, dan dari segi ekonomi apabila karya cipta didaftarkan akan memperoleh keuntungan berupa royalti.

Hukum bukanlah rumusan belaka, seperti hitam putih saja sebagaimana aturan dibuat tetapi hukum dibuat sebagai suatu gejala yang ada dalam masyarakat yang harus kita lihat dan amati. ${ }^{4}$ Budaya hukum dalam masyarakat merupakan tanggapan terhadap gejala-gejala hukum, tanggapan ini dimaksudkan menerima atau menolak suatu aturan yang ada didasarkan pada pola nilainilai yang hidup di dalam masyarakat. ${ }^{5}$

Adanya budaya hukum ini mampu membuat perbedaan berkerjanya hukum pada masyarakat yang satu dengan masyarakat yang lain. Masyarakat Indonesia memandang warisan budayanya tidak

Esmi Warrasih Pujirahayu, 2014, Budaya Hukum Pancasila, Tahafamedia, Yogyakarta, hlm.56. H. Hilman Hardikusuma, 1986, Antropologi Hukum Indonesia, Alumni, bandung, hlm.51 bersifat memiliki sebaliknya bersifat terbuka. Masyarakat Indonesia sangat tidak keberatan mengajarkan, membagi pengetahuan yang dia punya terhadap orang asing yang ingin belajar tentang kebudayaannya. Falsafah hidup kebersamaan ini mengajarkan masyarakat Indonesia untuk berbagi menjadi ciri kehidupan sosial menghargai kebersamaan keharmonisan dan keserasian dalam kehidupan kebersamaan

Ketidak pahaman masyarakat Indonesia tentang hak cipta disebab kan ketidaktahuan masyarakat akan bentuk serta perlindungan apa yang mereka dapat dari hak cipta. Seperti diBali, masyarakatnya bersifat komunal sangat sulit menerima konsepkonsep HKI yang menonjolkan hak-hak pribadi. Bagi masyarakat Bali,jikaadayang meniru hasil karya mereka baik seni maupun yang lain, Mengapa harusmelarangnya. Dalam masyarakat komunal kedudukan individu tidak lebih tinggi dari masyarakat. Menurut paham masyarakat tradisionl, individubukanlah individu yang kehilangan hak-hak individunya akan tetapi hak-hak individualnya itutidakterlalu ditonjolkan. Orientasinya adalahkedamaiandan kebahagianhidup bersama yang lebihtinggisehinggaklaimklaimHKImenjadisesuatu yang asing . ${ }^{6}$

Tataran normatif perlindungan negara terhadap karya cipta diatur dalam Undangundang Nomor 2014 Tentang Hak Cipta pada pasal 38 :

Agus Sardjono, 2009, Membumikan HKI di Indonesia, Nuansa Aulia Bandung, hlm.105. 
(1) Hak Cipta atas ekspresi budaya tradisional dipegang oleh Negara

(2) Negara wajib menginventarisasi, menjaga, dan memelihara ekspresi budaya tradisional sebagaimana dimaksud pada ayat (1).

Dalam penulisan jurnal ini warisan budaya dilihat dari bentuk ekspresi budaya dan pengetahuan tradisional dari masyarakat Indonesia, baik dalam bentuk tari, seni lukis, seni arsitektur, musik, tenun, batik, cerita dan seni terapan. Hukum memandang warisan budaya aspek perlindungnnya serta memberikan perlindungan hukum yang benar dan tepat serta dapat dipahami oleh anggota masyarakat sendiri. Dalam penulisan jurnal ini, akan mengambil objek permasalahan motif tradisional perak Bali. Penelitian kasus antara John Hardy, Ltd. Yang merupakan sebuah perusahaan asing melawan I Ketut Deni Aryasa, pengrajin perak diBali.John Hardy memiliki pabrik untuk membuat perhiasan di Bali bernama PT Karya Tangan Indah dan Deni Aryasa yang sebelumnya pernah bekerja pada John Hardy, sekarang menjadi kepala pendesain dan pemilik modal dari perusahaan bernama Bali Jewel.

Deni Aryasa ditahan di Bali dengan tuduhan menjiplak dua motif perhiasan milik John Hardy, yaitu Batu Kali dan Fleur (bung), pada perhiasan yang didesain oleh Deni Aryasa untuk Bali Jewel. PT Karya Tangan Indah memiliki gambar motif Bali yaitu motif batu kali yang diakui diciptakan oleh Guy Bedarida,yang berwarganegara Perancis gambar ini diregistert anggal 19 April 2006 pada Direktorat HAKI Jakarta.

Pentingnya penelitian hukum ini dilakukan, melihat kasus hukum di atas berkaitan dangan penegakan HKI dalam kerangka hak cipta apabila tidak diperhatikan dan ditangani secara khusus akan memberikan dampak negatif pada budaya hukum masyarakat mengenai aspek hukumdan aspek ekonomi, Budaya hukum merupakan komponen penting untuk memahami bekerjanya sistem hukum sebagai jembatan yang menghubungkan antara peraturan hukum dengan tingkah laku hukum seluruh warga masyarakat. Tanpa didukungnya oleh budaya hukum yang kondusif suatu peraturan atau hukum tidak bisa direalisasikan sebagaimana diharapkan baik oleh pembuat hukum maupun masyarakat yang sebagai sasaran dari hukum. Dari segi hukumnya hendaknya para pelaku seni dalam menciptakan karya seni mendafatarkan karya ciptanya ke Direktorat Jendral HAKI agar memperoleh perlindungan hukumatas karya ciptanya. Dari segi ekonomi dengan tidak mendaftarkan karya cipta membuat kerugian pada pencipta sendiri atas memperbanyak hasil karya cipta dan menggunakan hasil karya cipta dengan tidak mendapatkan royalti atas karya cipta yang didaftarkan.

Berdasarkan pemikiran tersebut, maka pada kesempatan ini peneliti sangat berminat untuk mengetahui dan menganalisa tentang budaya hukum pada pengrajin perak di Bali dalam hukum hak cipta. Dengan mengetahui budayahukumpengrajin perak diBali kiranya akan diketahui bagaimana perlindungan hukum hak cipta dalam kerajinan perak di Bali. Dengan demikian penelitian ini diberi Judul "Budaya Hukum Dalam Keberlakuan Undang-undang Nomor 28 Tahun 2014 Tentang Hak Cipta Pada Pengrajin Perak Bali”. 


\subsection{Rumusan Masalah}

Berdasarkan latar belakang masalah di atas, makarumusan masalah yang dapat dikemukakan dalam penelitian ini yaitu sebagai berikut :

1. Bagaimana bentuk perlindungan negara terhada pmotif-motif kerajinan perak Bali yang merupakan warisan tradisional?

2. Bagaimana budaya hukum pengrajin perakdi Bali terkait keberlakuan Undang-undang Nomor 28 Tahun 2014 tentang Hak Cipta?

\subsection{Tujuan Penelitian}

Adapun tujuan dari dilaksanakan penelitian ini yaitu :

1. Untuk mengetahui dan memahami perlindungan hukum yang diberikan oleh Negara terhadap motif-motif kerajinan perak Bali yang merupakan warisan tradisional.

2. Untuk mengetahui dan memahami budaya hukum pengrajin perak di Bali terkait dengan Undang-undang Nomor 28 Tahun 2014 Tentang Hak Cipta

\section{Metode Penelitian}

Berdasarkan uraian permasalahan yang di atas, jenis penelitian ini termasuk penelitian hukum empiris.Dalam penelitian hukum empiris.Pangkal tolak penelitian empiris terletak pada kenyataan yang ada di tengah-tengah masyarakat. ${ }^{7}$ Sifat penlitian ini adalah deskriptif yang bertujuan menggambarkan secara tepat sifat individu, gejala kelompok untuk menujukan ada tidak hubungannya antara suatu gejala dengan gejala yang lain di masyarakat. ${ }^{8}$ Data yang dingunakan disini menggunakan data primer yang berasal dari informan dan responden dan data sekunder yang berasal dari kepustakaan. Teknik pengumpulan data dalam penelitian ini adalah teknik studi dokumen dan teknik wawancara. Teknik Penentuan Sampel dalam penelitian ini menggunakan Non Probabilty Sampling dengan bentuk Snowball Sampling. Teknik pengolahan data dengan dilakukan analisis kualitatif.

\section{HASIL DAN PEMBAHASAN}

\subsection{Wujud Perlindungan Negara} Terhadap Motif - Motif Tradisional Perak Bali

Perlindungan terhadap karya cipta apabila suatu karya telah berwujud bukan ide semata dengan adanya bentuk dan merupakan hasil pemikiran sendiri dari pencipta secara otomatis memiliki perlindungan. Untuk memperoleh perlindungan hukum, pencipta harus melakukan pendaftaran ke Direktorat Jendral HAKI agar memperoleh surat pendaftaran sebagai bukti perlindungan apabila ada gugatan terhadap kerajinan yang dibuat. Negara Indonesia mempunyai hak cipta setelah melakukan Penandatangan perjanjian Putaran Urugay dalam rangka pembentukan WTO dan telah meratifikasi Undang-undang Nomor 7 Tahun 1994.

Permasalahan yang mendasar di Indonesiabelumadanya pencatatanyang jelas terkait dengan kebudayaan asli Indonesia adanya klaim dari pihak asing membuat

Bahder John Nasuition, 2008, Metode Penelitian Hukum, CV Mandar Maju, Jambi, hlm.125.

Amiruddin, H Zainal Asikin, 2008, Pengantar Metode Penelitian Hukum, PT Raja Grafindo Persada, Jakarta, hlm. 25. 
Indonesia harus mengkaji lagi sistem hukum untuk dapat melakukan perlindungan terhadap kebudayaan asli Indonesia. Pelaku Seni perak di Bali pernah mengalami kasus hukum mengenai pelanggaran hak cipta pada motif tradisional, penulis akan menggunakan dua contoh kasus pelanggaran hak cipta terhadap motif tradisional perak. Kasus pelanggaran hak cipta pertama dialami oleh Desak Nyoman Suarti, pada tahun 1985 Desak Nyoman Suarti seorang pengusaha perak yang tinggal di desa Pengosekan Ubud Bali. Suarti saat berada di Amerika digugat oleh pengusaha asing yang bernama Lois Hill di Pengadilan Negeri Amerika, dengan objek gugatan desain motif "anyaman". Lois Hill merupakan pengusaha asal Amerika, oleh pengusaha asing ini mendaftarkan motif anyaman ini di Amerika dan mendapat hak cipta atas nama pengusaha asing tersebut. Desain kerajinan perak dengan konsep anyaman itu pun telah menjadi milik warga asing dengan dilindungi serifikat HAKI. Di wilayah Negara Amerika Suarti masih kental dengan budaya Bali dengan motif tradisional Bali Suarti menjual kerajinan peraknya, kepada pengusaha asing dan konsumen asing dalam pameran yang diikuti di Amerika. Dari pameran ini mulailah terjadi permasalahan yang dihadapi Suarti dengan Lois Hill sebagai pemilik sah atas sertifikat hak cipta motif "anyaman", di mana saat transaksi jual beli perhiasan perak hasil karyanya, Suarti dikejar oleh pihak keamanan di Amerika karena adanya laporan melanggar hak cipta terhadap motif anyaman yang dimiliki oleh Lois Hill.
Desak Nyoman Suarti pada saat itu berada di Amerika segara dibawa ke Polisi untuk diminta keterangan atas laporan telah melakukan pelanggaran Hak Cipta. Sehingga Desak Nyoman Suarti segera dilakukan proses hukum dengan kasus pelanggaran hak cipta disidang pengadilan, Suarti digugat oleh pengusaha asing dengan kasus pelanggaran hak cipta dengan menjiplak konsep anyaman yang di mana pengusaha asing tersebut telah memiliki sertifikat hak cipta atas motif anyaman. Hal tersebut tentu membuat Desak Nyoman Suarti tidak menerima tuduhan yang dilakukan pengusaha asing kepadanya menjiplak konsep motif anyaman. Padakerajinan perak pendapat Suarti, motif anyaman merupakanbentukmotif tradisional masyarakat Bali yang biasa dipakai dalam membuat perhiasan perak.Merasa samasama memiliki hak atas konsep motif anyaman terjadilah perselisihan Suarti yang merupakan pengusaha lokal dengan oknum pengusaha asing yang telah memiliki sertifikat hak cipta atas motif"anyaman".

Desak Nyoman Suarti paham bahwa konsep anyaman itu adalah milik leluhur masyarakat Bali dan siapapun berhak memakainya. Perkara yang dituduhkan kepadanya tentang pelanggaran terhadap hak cipta atasmotif anyaman tidaklah tepat. Perkara hak cipta ini menjadi istimewa dan menjadi isu dunia Internasional karena seorang perempuan desa dari Bali yang berprofesi pengrajin digugat di Pengadilan Amerika, Suarti merasa yakin bahwa karya desain peraknya adalah murni kreasi kreativitasnya sendiri. Dengan keyakinan bahwa motif anyaman yang dipermasalahkan 
adalah nilai-nilai budaya tradisional sebagai warisan nenek moyang orang Bali dan bisa dimanfaatkan oleh siapapun dan tidak boleh dimiliki atau diklaim sebagaimilik pribadi/kelompok.Pada saat itu Suarti tidak mengetahui mengenai hak cipta hanya bermodalkan pengetahuan yang dia dapat tentang motif tradisional Bali dan memberi penjelasan mengenai desain anyaman yang digunakan dalam membuat perhiasan perak.Suarti melakukan perlawanan Lois Hill yang merupakan pengusaha asing yang dirasa telah merampas nilai-nilai tradisional Bali.Di Pengadilan Negeri Amerika akhirnya dimenangkan oleh Suarti dalam sidangpengadilan Negeri Amerika memutusakan bahwadesain anyaman sepenuhnya milik masyarakat Bali dan tidak bisa diklaim sebagai milik individu/kelompok. Sertifikat HAKI atas nama pengusaha asing tersebut dibatalkan demi hukum, dan Desak Nyoman Suarti yang merupakan pengusaha perak dari Bali dibebaskan dari segala tuntutan hukum.

Kasus yang kedua, Pelanggaran hak cipta terhadapmotiftradisional penulis menggunakan contoh Kasus Deni Aryasa, yang merupakan pengrajindari Bali yang dituduh menjiplak motif perusahan perak milik John Hardy pengusaha asing yang nama usahanya PT Karya TanganIndah. Kasus ini bermuladari tanggal 2 February2007, bertempat tadi Jalan Kajanti 18 Denpasar Lebih dari10 orang yang mengaku PPNS dan Mabes Polri Jakarta datang dan mengobrak ngabrik rumah Ketut Deni Aryasa. Mereka mencari barang bukti berupa perhiasan perak dengan motif Bali dan motif Crocodile atas nama Dewa Nyoman. Penyerangan itu tanpa membawa ijin, surat laporan ketua RT dan identitas apapun, mereka salah tangkap karena sebenarnya mereka cari Dewa Nyoman tetapi yang mereka geledah adalah rumah Ketut Deni Aryasa. Setelah menyita beberapa baranga bukti meraka pun pergi. Satu bulan selanjutnya barulah mereka mengirimkan surat ijin ke rumah Deni. Bahwa pada tanggal 11 Mei 2007 Ketut Deni Aryasa ditahan oleh POLDA dengan tuduhan Penjiplakan motif Fleur, motif batu kali dan motif buaya yang dilakukan kepada PT Karya Tangan Indah. Bahwa pada tahun 2000-2003 Ketut Deni Aryasa yang pernah berkerja di PT Karya Tangan Indah yang berlamat di Banjar Batuning Nomor 1 Mambal Badung, yaitu sebuh perusahaan yang bergerak di bidang produksi perak dan emas dan untuk setiap karya cipta ataupun desain industri yang dibuat oleh PT Karya Tangan Indah telah didaftarkan pada Direktorat Jendral HKI sebanyak 843 desain telah memperoleh sertifikat sejumlah kurang lebih 500 desain di antaranya : seni motif Kali didaftarakan hak cipta dengan nomor 030383 pada tanggal 19 tahun 2006, seni motif Fleur 1 nomor 030376 tanggal 19 April 2006, seni motif judul "Batu Kali Kombinasi " nomor 030378 tanggal 19 April 2006 dan seni motif judul Kali 2 nomor 030387 tanggal 19 April 2006 semua motif tersebut atas nama pencipta Guy Rainer Gabriel Bedarida, Sedangkan pemegang hak ciptanya adalah PT Karya Tangan Indah.

Ketut Deni Aryasa pengrajin perak Bali yang dituduh menjiplak motif perusahaan perak milik asing PT Karya Tangan Indah 
melakukan perlawanan dengan menyatakan motif yang digunakan ini adalah motif milik kolektif masyarakat yang sudah ada sejak dahulu bukan milik perseorangan tapi mengapa bisa dimiliki oleh orang asing. Deni dalam contoh motif fleur (bunga) yang dituding menyebar luaskan motif bunga padahal motif ini adalah salah satu motif tradisional Bali yang kaya akan makna. Motif seperti ini dapat ditemui di hampir seluruh ornament seni di Bali, seperti gapura rumah dapat ditemui dalam tempat persembahyangan umat Hindu di Bali seperti pura, sangat disayangkan motif tradisional ini dimiliki oleh orang asing.

Pengertian motif Berdasarkan hasil wawancara dengan Dr.Tjorkorda Udiana Nindhia Pemayun, S.Sn, S.H, M.Hum (Dosen Fakultas Seni Rupa Desain ISI) bertempat di Jalan Nusa Indah, Denpasar pada tanggal 16 April 2014, menyatakan pengertian motif tradisional adalah gambaran dari beberapa bentuk yang distrilisasi atau digayakan oleh seniman menjadi sebuah bentuk. Ada juga motif merupakan gambaran awal yang ada pada benak seniman untuk mewujudkan suatu karya. Menurutnya terdapat perbedaan konsep antara motif dan desain. Motif sudah tergambarkan dalam dua dimensi artinya motiftersebutsudah dituangkan dalam sebuah wujud. Sedangkan desain mewujudkan rancangan ide-ide dan gagasan yang masih bersifat abstrak yang kemudian diaplikasikan menjadi suatu perwujudan. Sedangkan kata tradisional merujuk pada pengertian tradisi sesuatu yang dikerjakan secara berulangulang atau berulang kali sampai finish. Motif tradisional sendiri dibagi menjadi berbagai jenis yaitu kekarangan, bebatuan, dan bunga. Dari Jenis kekarangan ini dibagi menjadi beberapa varian yaitu : karang asti, karang tapel, karang guak dan karang bentulu. Varian merupakan turunan dari jenismotif tersebut .(hasilwawancaratanggal 16 April2015).

Berdasarkan hasil wawancara dengan Desak Nyoman Suarti (Ketua Forum Peduli Budaya Bangsa) bertempat di Jalan Raya Celuk No100 Gianyar Bali pada tanggal 9 April2015) Suarti menyatakan pengertian motif tradisional perak Bali adalah gambaran yang ada dalam kehidupan sehari-hari dan ditemui pada arsitektur Bali. Motiftradisional perak Balibentukatauragam hias tradisional yang memiliki simbol ekspresi dan konstruktif tidak lepas dari filosofis spritual agama Hindu sebagai narasi besar, unsur-unsur tersebut lebih menambahkan keyakinan yang mendalam pada perwujudannya. Karya seni memliki fungsi religius dan fungsi sosial terjaga dan tetap berkembang bersama dengan keberadaan agama Hindu, elemen estetika pada media ritual Agama Hindu,sebagi simbol ekspresif individu dan simbolisekspresif konstitutif, bermakna sakral dan dijadikan objek kreasi kreatif oleh pengrajin atau perkerja seni lainnya. Demikian halnya dengan mengolah bahan perak sesuai dengan pengalaman pengetahuan dan keterampilan sehingga mampu menciptakan desain perak. Dengan gambaran seperti di atas desain kerajinan perak yang diciptakan nasih tetap memiliki nilai trasidional. Dalam penciptanya tergantung dalam kemampuan dan kepekaan individu, sehingga perwujudannya menjadi variatif, pada hakikatnya motif ragam hias dijadikan elemen-elemen estetika pada 
desain kerajinan perak di Desa Celuk sifatnya sakral.(hasil wawancara 9 April 2015).

Untuk memahami pengertian motif tradisional, Nyoman Patra S.H., M.H., Ketua Asosiasi Perak Bali menyatakan terlebih dahulu harus ditentukan periode pemunculannya. Seperti batasan motif tradisional ini harus dibuat waktu dulu dari zaman prasejarah, yang secara sederhana dimulai dari zaman batu, zaman logam baru ke zaman perkembangan. Dengan demikian motif tradisional bisa juga merupakan hasil modifikasi dari zaman ke zaman, yang didapat dari pergaulan antar daerah antarnegara yang akan dimodifikasi oleh pengrajin. Dinyatakan, seni itu hasil kreativitas tidak bisa dikekang, yang nantinya mampu menghasilkan nilai ekonomi yang tinggi.

Berdasarkan pasal 39 ayat 1 Undangundang Hak Cipta. Negara memegang hak cipta atas kepemilikan ciptaan yang tidak diketahui hak ciptanya. Disini Negara memegang hak cipta atas ekspresi budaya ciptannya tidak diketahui penciptanya tujuan tidak lain untuk melakukan perlindungan hasil kebudayaan rakyat pemerintah dapat mencegah adanya monopoli dagang dan pemanfaatan budaya yang dilakukan oleh pihak asing sehingga apabila pihak asing melakukan pemanfaatan budaya Indonesia wajibmeminta izin padaMenteri Kebudayaan dan Pariwisata. ${ }^{9}$

Dalam kententuan hak cipta ada dua model perlindungan diberikan pertama perlindungan preventif yang bersifat pencegahan pencipta melakukan pendaftaaran terhadap karya ciptanya.

Gatot, Supromo, 2010, Hak cipta dan Aspek-aspek Hukumnya, Rineka Cipta, Jakarta, hlm.5.
Sedangkan model perlindungan yang kedua perlindungan represif yaitu berupa tindakan hukum. ${ }^{10}$ Apabila pencipta merasa dirugikan pencipta bisa melakukan proses hukum baik dengan perkara perdata atau pidana. Perlindungan hukum perdata dimuatnya hak-hak pencipta dengan diatur dalam pasal 1365 KUHper sebagai dasar melakukan perlindungan dan meminta biaya ganti rugi. Sedangkan pada perlindungan pidana berupa sanksi hukum atas perbuatan yang dilakukan pelanggar tujuannya untuk menimbulkan efek jera.

\subsection{Aspek Budaya Hukum Pengrajin Perak Bali Terhadap Keberlakuan Undang -Undang Nomor 28 Tahun 2014 Tentang Hak Cipta}

Berdasarkan uraian di atas, maka dapat dikonstruksikan budaya hukum pengrajin perak yaitu seperangkat pengetahuan, nilainilai dan keyakinan yang dimiliki oleh komunitas pengrajin perak untuk pedoman dalam mentaati peraturan hukum.Budaya hukum dari pengrajin merupakan mesin yang dapat menggerakkan pengrajin untuk bertindak sebagai pihak dalam mendaftarkan karyanya ke dalam sistem perlindungan HKI pilihan pengrajin dalam mendaftarkan karyanya atau tidak, akan tergantung dan mengikuti oleh suatu sistem budaya yang dianut. Sistem nilai budaya akan menjadi pedoman yang menunjukkan suatu arah maupun orientasi pada kehidupan dirinya di lingkungan budayanya. Sistem budaya itu berisi tentang ide, gagasan, nilai-nilai,

Adami Chazawi, 2007, Tindak Pidana Hak Atas Kekayaan Intelektualitas, Bayumedia,Malang, hlm.15. 
norma-norma, dan peraturan yang hidup dalam persepsi di dalam komunitas pengrajin perak sendiri. Sistem budaya berada di wilayah emosional dari alam kejiwaan dari pendukung kebudayaan yang bersangkutan.

Gambaran umum yang diperoleh mengenai budaya hukum di daerah tersebut adalah karya itu untuk nafkah hidup. Wawancara terhadap I Nyoman Patra selaku Ketua Asosiasi Perak Bali menyatakan pengrajin selama ini belum banyak mengerti mengenai hak kekayaan intelektual. Pengrajin hanya berfokus pada pengerjaan proses produksi. Namun sejak ada kasus pelanggaran HKI yang dialami Ketut Deni Ariyasa, maka pengrajin perak mulai memahami pentingnya HKI. Cokorda Udiana Nindhia Pemayun selaku saksi ahli dalam perkara HKI juga menyatakan sebagian besar pengrajin perak belum mencapai tataran untuk mengetahui HKI maupun pentingnya HKI. Seringkali pengrajin tidak mencamtumkan bagaimana asal usul penciptaan suatu motif yang pengrajin kreasikan. Tahapan-tahapan dalam proses penciptaan suatu karya kerajinan perak yang memuat suatu motif seringkali tidak dapat dibahasakan secara tertulis oleh pengrajin. Mereka mendapatkan suatu inspirasi tanpa mampu menuangkannya dalam suatu tahapan substansif suatu karya. Sehingga pengrajin perak selaku pencipta belum tentu menjadi pemegang hak cipta dari motif karyanya.

Menurut I Nyoman Patra, orientasi nilai budaya pengrajin perak khususnya di daerah Gianyar selama ini memandang karya itu untuk hidup. Mereka dalam bekerja mengedepankan asas gotong royong dan kebersamaan, bahkan memang cenderung komunal. Sifat individualistis akan menjadikan pribadi minoritas di kalangan rekanannya. Sehingga pemahaman yang terjadi dalam tataran empiris adalah penggunaan motif secara bersama sama.

Hal yang sama pula dikemukan oleh I Ketut Muja selaku pengrajin perak di Klungkung. dalam kalangan pengrajin di Klungkung, hal yang sangat lumrah dalam bekerja menggunakan asas kebersamaan. Bukan menjadi suatu pakem untuk bersifat tertutup dan kaku terhadap suatu motif. Bersama-sama dengan sesama pengrajin perak di daerah Klungkung, mereka menggunakan motif-motif yag sama untuk kerajinan perak bokor, tempat tirta, maupun peralatan untuk sarana upacara agama.

Pemberlakuan suatusecara nyata dalam kehidupan masyarakat sangat dipengaruhi oleh kondisi sosiologis masyarakat.Secara sosologis suatudirancang, dibentuk dan diberlakukan tidak bisa lepas dari gejala sosial, ekonomi, politik dan kebudayaan yang hidup dan berkembang dalam masyarakat. yang dibuat tanpa memperhatikan halhal tersebut akan dianggap hukum asing masyarakat, karena tidak berakar dari realitas sosial. Akibatnya kepatuhan hukum yang diharapkan tidak terjadi danyang bersangkutan tidak memberikan dampak sebagaimana yang diinginkan oleh pembentuk.

Adapun faktor-faktor yang mempengaruhi nilai budaya hukum pengrajin perak Bali terhadap keberlakuan Undangundang Nomor 28 Tahun 2014 tentang Hak Cipta 
1. Adanya Pengetahuan Tentang Hukum

Dalam tataran pengetahuan hukum yang dimiliki oleh pengrajin perak Bali, sebagian besar memiliki pengetahuan hukum yang terkait hak kekayaan intelektual. Wawancara yang dilakukan terhadap Desak Nyoman Suarti selaku seorang maestro di bidang perak,memahami secara garis besar pemaknaan hak kekayaan intelektual. Suarti mencoba untuk belajar hak kekayaan intelektual dan kerap mendiskusikan HKI sebagai isu hukum dalam grup-grup diskusi bersama rekan-rekannya.dan aktif dalam forum peduli budaya bali. Pengetahuan hukum yang diperoleh dilatari dengan semangat untuk menyelamtakan roh etnik dari kerajinan perak Bali.

Wawancarayang dilakukan selanjutnya kepada I Nyoman Patra selaku Ketua Asosiasi Perak Bali.mengatakan pemahaman terhadap Hak Kekayaan Intelektual sekarang jauh lebih berkembang dan pengrajin sudah memiliki pengetahuan tentang hak kekayaan intelektual. Latar belakangnya adalah melihat peristiwa hukum klaim pelanggaran hak cipta oleh Deni Ariyasa versus John Hardy.Dengan adanya kasus hukum seperti itu, para pengrajin perak mengalami suatu momentum untuk belajar dan mengetahui hak kekayaan intelektual. Pengetahuan hukum yang dimiliki pengrajin perak secara garis besar hanya mengetahui bahwa perlunya bagi pengrajin perak untuk mendaftarkan hasil karyanya.Sementara tantangan yang dihadapi pengrajin perak adalah biaya untuk mendaftarkan.Bagi sebagian pengrajin timbul suatu sifat enggan untuk mendaftarkan karena penghitungan biaya mendaftarkan, ongkos produksi dan hasil yang didapat.

2. Adanya Penghayatan Fungsi Hukum

Fungsi atau peranan hukum terhadap segi-segi kehidupan masyarakat mengalami perkembangan dan perubahan. Dalam sejarah pemikiran ilmu hukum terdapat dua paham yang berbeda. Paham pertama mengatakan bahwa fungsi hukum hanyalah mengikuti perubahan-perubahan itu dan sedapat mungkin mengesahkan perubahanperubahan yang terjadi dalam masyarakat. Pendapat ini dipelopori oleh mazhab sejarah dan kebudayaan yang diajarkan oleh Friedrich Carl von Savigny. ${ }^{11}$

Penghayatan fungsi hukum oleh pengrajin perak belum dapat dilaksanakan sepenuhnya. Hukum hak kekayaan intelektual berperan dalam mengatur dan melindungi suatu karya intelektual yang sudah diwujudkan belum diterima secara sepenuhnya dalam komunitas pengrajin. Hukum itu baru terwujud pada saat terjadi pelanggaran di bidang HKI. Pada saat proses penciptaan karya suatu kerajinan, sebagian besar pengrajin tidak mendaftarkan karyanya. Mereka melihat dari persepektif ekonomis suatu karya, bagaimana suatu karya bisa menembus pasar tanpa melindunginya dengan aspek hukum.

3. Ketaatan terhadap Hukum

Taat terhadap hukum tidak sama dengan menerapkan huruf-huruf peraturan begitu saja, tetapi mencari dan menemukan

H. Riduan Syahrani, op.cit, hlm.29 
makna sebenarnya dari suatu peraturan dengan kecerdasan spiritual, yaitu : pertama, penggunaan kecerdasan spiritual untuk bangun dari keterpurukan hukum, kedua pencarian makna lebih dalam hendaknya menjadi ukuran baru dalam menjalankan hukum dan bernegara hukum, apa makna peraturan, prosedur, asas, doktrin dan lainnya. Ketiga, hukum hendaknya dijalankan tidakmenganut prinsip logika saja tetapi dengan perasaan, kepedulian dan semangat keterlibatan kepada bangsa, khususnya bangsa Indonesia yaitu berdasarkan pancasila. $^{12}$

Pancasilamenjadi landasan atas budaya hukum bangsa Indonesia. Hukum harus berdasarkan pada pancasila, produk hukum boleh dirubah sesuai dengan perkembangan zaman dan pergaulan masyarakat, tentunya pancasila harus menjadi kerangka berfikir. Dari uraian pembahasan pada sub bab terdahulu, dapat dimunculkan dua hal dalam budaya hukum yaitu : ketentuan hukum yang ada dan bentuk penegakan hukum yang dijalankan. Untuk menciptakan budaya hukum yang positif dan dapat mendukung tata kehidupan masyarakat, kedua komponen tersebut diperlukan. Apabila pemerintah dapat meyakinkan kepada masyarakat bahwa hukum yang dibentuk itu adalah berorientasi pada rakyat dan berkeadilan sosial, para penegak hukum dalam menjalankan tugasnya bersifat non diskriminatif, tentu saja masyarakat akan memberi dukungan dan sekaligus akan mengikuti pola tersebut. Agar hal ini dapat berjalan baik maka

12 Abdul Manan, 2005, Aspek-aspek Pengubah Hukum, Kencana Prenada Media Grup, Jakarta. hlm.3. pemerintah harus menciptakan masyarakat yang terdididik supaya masyarakat dapat memahami dengan baik dan melaksanakan aturan hukum yang telah dibuatnya. Sehingga berbicara budaya hukum juga berbicara kesadaran hukum masyarakat. Untuk mengkonstruksi budaya hukum yang ideal bagi masyarakat tidak cukup hanya mempergunakan secara konvensional ilmu hukum saja, tetapi perlu mempergunakan berbagai faktor yang berkembang saat ini, terutama hal-hal yang menyangkut pemikiran kembali apa yang menjadi tujuan hukum dan redefinisi tentang fungsi hukum dan peranan hukum dalam masyarakat. Dengan demikian budaya hukum maupun kesadaran hukum masyarakat merupakan dua hal yang dapat dikembangkan secara terpadu, sehingga pembaharuanhukumyangdapatdilaksanakan itu dapat diterima oleh masyarakat sebagai pedoman tingkah laku yang harus dituruti. Bila dicermati permasalahan penegakan hukum di Indonesia dapat dibagi dalam tiga komponen bagian permasalahan mendasar dikaitkan dengan Teori Sistem Hukum oleh Lawrence M Freidman yang merupakan berjalannya Sistem Hukum di suatu Negara, keberadaan sistem hukum yang terdapat dalam masyarakat sebagai berikut $:^{13}$

Pertama, struktur hukum berkaitan dengan lembaga yang berwenang melakukan penegakan hukum.Masalah hak cipta aparat penegak hukumnya Penyidik PPNS, polisi, jaksa dan hakim penegakan hukum di Indonesia belum menguasai dan mengerti kekayaan Intelektua dan hak cipta masih

\footnotetext{
Saifulah , 2011, Refleksi Sosiologi Hukum ,Reflika Aditama, Bandung, hlm.26.
} 
belum memadai seperti perubahan Undangundang Hak Cipta dahulunya menggunakan delik biasa sekarang menggunakan delik aduan membuat kuantitas kerja aparat bertambah sedangkan pengetahuan hukum aparat masih belum paham betul dengan delik biasa menjadi delik aduan membuat aparat penegakan hukum belum mendapat pemahaman secara merata. Kedua, substansi hukum berkaitan dengan isi hukum, norma hukum yang dibuat negara. Perubahan Undang-undang Hak Cipta di Indonesia adanya tuntutan untuk menyesuaikan dengan perkembangan ekonomi serta keikut sertaan Indonesia dalamkonvensi-konvensi Internasional sehingga dilakukan perubahan yang aturan peran sesuai dengan isi konvensi sedangkan beberapa ketentuan konvensi Internasional tidak sesuai dengan Negara Indonesia. Ketiga, budaya hukum adalah sikap dan nilai yang ada hubungannya dengan hukumdan sistemhukum.Perlindungan hak cipta di Indonesia menggunakan konsep baratdenganmenonjolkan kepentingan individu sedangkan budaya hukum pengrajin bersifat komunal sehingga penerapan Undang-undang hak cipta susah diterapkan bersifat asing bagi pengrajin dengan menonjolkan kepentingan pribadi tidak bersandar pada nilai-nilai yang hidup dalam pengrajin.

\section{PENUTUP}

\subsection{Simpulan}

Adapun simpulan yang dapat ditarik dari uraian pembahasan di atas adalah :

1. Bentuk perlindungan negara terhadap motif-motif tradisional kerajinan perak Bali yang merupakan warisan budaya tradisionalada dua yaitu perlindungan hukum preventif adanya pendaftaran terhadap karya cipta dan kedua perlindungan represif pemberian sanksi apabila ada yang melanggar ketentuan hak cipta.

2. Budaya hukum pengrajin perak di Bali terkait keberlakuan Undangundang Nomor 28 Tahun 2014 adalah memandang motif tradisional sebagai hakikat karya dengan orientasi karya itu untuk nafkah hidup. Sistem nilai yang dianut sebagian besar pengrajin perak di Bali tidak mendaftarkakan karyanya ke dalam hak cipta.

\subsection{Saran}

Adapun saran yang dapat diberikan terhadap uraian pembahasan di atas sebagai berikut :

1. Pemerintahkhususnya Departemen Hukum dan HAM bertindakaktif dalam melakukan sosialisasi HKI kepada masyarakat.

2. Peranmasyarakat disini ditujukan kepada Asosiasi yang melibatkan komunitas pengrajin perak. Asosiasi disarankan untuk membuat klinik HKI yang menunjang kegiatan anggotanya. Klinik HKI diharapkan mampu memberikan edukasi kepada komunitas pengrajin perak. 


\section{DAFTAR PUSTAKA}

Amirudin dan H.Zainal Asikin, 2008, Pengantar Metode Penelitian Hukum, PT. Raja Grafindo Persada, Jakarta.

Chazawi, Adami, 2007, Tindak Pidana Hak Atas Kekayaan Intelektualitas, Bayumedia,Malang.

Hardikusuma,H. Hilman, 1986, Antropologi Hukum Indonesia, Alumni, Bandung.

Johan,Bahder Nasution, 2008, Metode Penelitian Ilmu Hukum, CV.Mandar Maju, Jambi.

Manan,Abdul, 2005, Aspek-Aspek Pengubah Hukum,Kencana Prenada Media Group, Jakarta.

Syahrani, H.RiduanSyahrani,2011, RangkumanIntisariIlmu Hukum, PT. Citra Aditya, Bandung.

Saifulah , 2011, Refleksi Sosiologi Hukum,Reflika Aditama, Bandung.

Supromo, Gatot, 2010, Hak cipta dan Aspek-aspek Hukumnya, Rineka Cipta, Jakarta.

Sardjono,Agus, 2009, Membumikan HKI di Indonesia, Nuansa Aulia, Bandung.

Warrasih,Esmi Pujirahayu, 2014, Budaya Hukum Pancasila, Tahafamedia, Yogyakarta

\section{JURNAL}

Mastur, Perlindungan Hukum Hak Kekayaan Intelektual di Bidang Paten, Jurnal Ilmiah Hukum Vol 6, No1, Edisi 1 Januari 2012, Fakultas Hukum, Universitas Wahid Hasyim Semarang. http// portal garuda article $/ \mathrm{PHP} /$ article $=134251 \&$ Val 5636. di akses 27 April 2015.

\section{PERATURAN \\ PERUNDANG-UNDANGAN}

Undang-undang Nomor 28 Tahun 2014 tentang Hak Cipta (Tambahan Lembaran Negara Republik Indonesia Tahun 2014 Nomor 266)

Nama : Kadek Julia Mahadewi

Alamat: J1 Kapten Agung No 7A Denpasar No HP : 08174196556

E-mail:juliamahadewi@gmail.com 